\title{
Increased PMA-induced chemiluminescence from whole blood of patients with bronchial hyperreactivity
}

\author{
S. Nordman, P. Nyberg, L. Linko
}

Increased PMA-induced chemiluminescence from whole blood of patients with bronchial hyperreactivity. S. Nordman, P. Nyberg, L. Linko. CERS Journals Ltd 1994.

ABSTRACT: Blood phagocytes from patients with asthma have an increased capacity to produce reactive oxygen metabolites. We studied whether whole blood luminol-dependent chemiluminescence could detect this phenomenon in patients with a normal spirometry but bronchial hyperreactivity as determined with a methacholine bronchial challenge test.

Whole blood chemiluminescence, serum eosinophilic cationic protein (ECP), and serum myeloperoxidase (MPO) were determined from 50 patients referred for a methacholine challenge due to prolonged cough and/or dyspnoea. The chemiluminescence results were compared to those from 15 healthy persons.

The hyperreactive patients $(n=18)$ had significantly higher phorbol 12-myristate 13-acetate (PMA)-induced whole blood chemiluminescence values (mean 18.8 $\mathrm{mV} \cdot \mathrm{min}^{-1} ; 95 \%$ confidence limits (C.L.) $16.3-21.3 \mathrm{mV} \cdot \mathrm{min}^{-1}$ ) than the normoreactive patients (mean $14.2 \mathrm{mV} \cdot \mathrm{min}^{-1} ; 95 \%$ C.L. 13.0-15.5 $\mathrm{mV} \cdot \mathrm{min}^{-1}$;) and the healthy controls (mean $12.8 \mathrm{mV} \cdot \mathrm{min}^{-1} ; 95 \%$ C.L. $11.7-13.9 \mathrm{mV} \cdot \mathrm{min}^{-1}$ ). There was no significant difference in PMA-induced chemiluminescence between the normoreactive patients and the controls. The hyperreactive patients had higher serum ECP values than the normoreactive patients, but there was no correlation between whole blood chemiluminescence and serum ECP levels or total eosinophil count. There was no significant difference in monocyte reactive oxygen metabolite production or serum MPO values between the normoreactive and the hyperreactive patients.

We suggest that the increased PMA-induced whole blood chemiluminescence in bronchial hyperreactivity is due mainly to an activation of neutrophils, and that the assay might be useful as a systemic inflammatory marker in patients with pulmonary inflammatory processes resulting in bronchial hyperreactivity.

Eur Respir J., 1994, 7, 1425-1430.
Mjölbolsta Hospital, Finland.

Correspondence: P. Nyberg

Mjölbolsta Hospital

SF-10350 Mjölbolsta

Finland

Keywords: Asthma

bronchial hyperreactivity

chemiluminescence

eosinophilic cationic protein

myeloperoxidase

reactive oxygen metabolites

Received: May 281993

Accepted for publication May 101994

This work was financially supported by grants from Finska Läkaresällskapet, the Nummela Foundation for Medical Research, the Mjölbolsta Foundation for Medical Research, and Astra Draco AB, Lund, Sweden.
Inflammatory processes are important in the pathogenesis of asthma [1, 2]. Histological and cytological studies have shown an accumulation of phagocytes, i.e. eosinophil and neutrophil granulocytes, monocytes and macrophages, in the airway mucosa and alveolar space of asthmatic subjects [3]. These changes are present even at a clinically early stage of the disease [4]. All phagocytes contain an enzyme complex, the NADPH oxidase, which following activation catalyzes the production of the superoxide radical [5]. From superoxide, other reactive oxygen metabolites (ROMs) may be formed [6]. An inappropriate activation of the reduced nicotinamide adenine dinucleotide phosphate (NADPH) oxidase, the physiological role of which lies in the defence against microbes [7], may be involved in the pathogenesis of numerous diseases, including bronchial asthma [8].

Several studies have shown that the ROM metabolism of lung phagocytes is activated in asthma [9-14], but there are also reports of an increased ROM production by peripheral blood phagocytes of asthmatic subjects
[15-20]. Peripheral blood phagocyte ROM production may, thus, be useful as a systemic inflammatory marker in asthma. Most of the above-mentioned blood phagocyte studies have been performed using cumbersome techniques, involving time-consuming cell isolation procedures, which decreases the potential for clinical use of these methods. However, ROM production by blood phagocytes may also be estimated with whole blood chemiluminescence, a simple and rapid assay which measures mainly neutrophil-derived hypochlorous acid production [21, 22].

The diagnosis of asthma is usually based on a typical history, together with the demonstration of reversible airflow obstruction [23]. When asthma is being considered but the patient has no current signs of reversible airflow obstruction in lung function tests, measurement of bronchial hypereactivity with methacholine or histamine challenge tests may be useful [24]. The aim of the present study was to evaluate whether an increased ROM production by peripheral blood phagocytes may be detected with whole blood chemiluminescence in patients 
with respiratory symptoms and bronchial hyperreactivity suggesting asthma, but with normal prechallenge spirometry values. For comparison, we also determined the serum eosinophilic cationic protein (ECP) and myeloperoxidase (MPO) levels, which have been suggested as systemic markers of phagocyte-induced inflammation $[25,26]$.

\section{Materials and methods}

\section{Reagents}

Phorbol 12-myristate 13-acetate (PMA) and zymosan A yeast were purchased from Sigma, USA. Zymosan was opsonized with normal human serum, as described previously [27]. Luminol (5-amino-2, 3-dihydro-1, 4phthalazinedione) was obtained from Bio-Orbit, Turku, Finland; phosphate buffered saline (PBS) from Gibco, Paisley, UK; and Ficoll-Paque from Pharmacia, Uppsala, Sweden.

\section{Patients}

Fifty consecutive patients referred for a methacholine challenge test due to respiratory symptoms suggesting asthma, but with a normal forced expiratory volume in one second $\left(\mathrm{FEV}_{1}\right)$, were included in the study. Fifteen healthy volunteers with no respiratory symptoms formed a control group. Twenty of the patients suffered from prolonged cough and dyspnoea, 22 from prolonged cough only, and 8 from dyspnoea only. All patients were skin tested with 24 common allergens (Soluprick ${ }^{\circledR}$, Allergologisk laboratorium A/S, Denmark), and atopy was confirmed, with at least one abnormal response, in 13 cases. Nineteen $(38 \%)$ of the patients had used no medication before the methacholine challenge. Twenty (40\%) of the patients had used topical $\beta_{2}$-agonists, $3(6 \%)$ oral antihistamines, $5(10 \%)$ nasal steroids, and $3(6 \%)$ combinations of the above. $\beta_{2}$-agonists were withheld for 12 hours before the bronchial challenge, and oral antihistamines for at least two weeks.

\section{Methacholine challenge}

Methacholine challenge was performed with a Spira Elektro 2 dosimeter with controlled tidal breathing (Respiratory Care Center, Hämeenlinna, Finland) [28], using a slight modification of the protocol described by NIEMINEN et al. [29]. Methacholine was inhaled in five cumulative doses $(18,72,270,800$, and 2,600 $\mu \mathrm{g})$. Three minutes after each methacholine dose, the change in $\mathrm{FEV}_{1}$ from the prechallenge value was measured. The test was interrupted when $\mathrm{FEV}_{1}$ fell by at least $20 \%$ of the prechallenge value, or when the maximum methacholine dose $(2,600 \mu \mathrm{g})$ was reached. The fall in $\mathrm{FEV}_{1}$ was plotted against methacholine dose on a log scale, and the provocative dose causing a $20 \%$ fall in $\mathrm{FEV}_{1}\left(\mathrm{PD}_{20} \mathrm{FEV}_{1}\right)$ was calculated. The patients with a $\mathrm{PD}_{20} \mathrm{FEV}_{1} \leq 2,600$ $\mu \mathrm{g}$ methacholine were considered hyperreactive.

\section{Blood samples}

Twenty millilitres of heparinized blood for the chemiluminescence assays and $20 \mathrm{ml}$ of nonheparinized blood for the enzyme assays were obtained by venepuncture from each person participating in the study, within 30 min before the methacholine challenge. Haemoglobin concentration, leucocyte count, and an automatic differential count were determined with an S-Plus JR Counter Coulter (Coulter Electronics Ltd, Luton, UK). The eosinophil count was determined manually using MayGrünwald-Giemsa (MGG)-stained specimens for the first 28 participants of the study.

\section{Whole blood chemiluminescence}

Whole blood chemiluminescence was determined within $15 \mathrm{~min}$ after venepuncture. The reaction suspensions contained $100 \mu \mathrm{l}$ of heparinized blood, $100 \mu \mathrm{l}$ luminol $\left(5.6 \times 10^{-3} \mathrm{M}\right), 100 \mu \mathrm{l}$ PMA $\left(1 \mu \mathrm{g} \cdot \mathrm{ml}^{-1}\right)$, or $150 \mu \mathrm{l}$ opsonized zymosan $\left(1 \mathrm{mg} \cdot \mathrm{ml}^{-1}\right)$, and phosphate buffered saline (PBS) ad $1 \mathrm{ml}$. The reactions were started by adding PMA or opsonized zymosan, and the resulting light emission was recorded for $20 \mathrm{~min}$ at 2 min intervals with a micro-computer-controlled luminometer (Bio-Orbit, Turku, Finland). The reactions were performed at $37^{\circ} \mathrm{C}$, and all measurements were performed in duplicate. The results are expressed as areas under the light emission curves $\left(\mathrm{mV} \cdot \mathrm{min}^{-1}\right)$. The intra-assay reproducibility of the results was determined on five separate occasions with six parallel samples: the coefficient of variation $(\mathrm{CV} \%)$ of the parallel samples was $5.3 \pm 2.0 \%$ (mean value $\pm \mathrm{SD}$ ).

\section{Isolation of mononuclear leucocytes}

Mononuclear cells (monocytes and lymphocytes) were isolated from the first 35 patients included in the study (21 normoreactive and 14 hyperreactive). Ten millilitres of heparinized blood was centrifuged on Ficoll-Paque at $450 \times \mathrm{g}$ for $30 \mathrm{~min}$, after which the cells were washed twice in PBS at $450 \times \mathrm{g}$ for $10 \mathrm{~min}$. The cells were counted and the cell number was adjusted to $10 \times 10^{6} \mathrm{cells} \cdot \mathrm{ml}^{-1}$. The monocyte content was determined using MGG-stained cytocentrifuge preparations.

\section{Mononuclear leucocyte chemiluminescence}

Fifty microlitres of the mononuclear cell suspension was incubated in luminol at $37^{\circ} \mathrm{C}$ for $10 \mathrm{~min}$. After incubation, the chemiluminescence assay was performed as described above. The results are expressed as areas under the light emission curves $\left(\mathrm{mV} \cdot \mathrm{min}^{-1}\right) \cdot 10^{-5}$ monocytes. 


\section{ECP and MPO assays}

Serum ECP and MPO were determined using commercially available double antibody radio-immunoassays (Pharmacia, Uppsala, Sweden). The ECP assay has been described in detail by PETERSON et al. [30], and the MPO assay is based on the method described by OLOFSSON et al. [31]. The results from the enzyme assays were compared to values obtained from 17 healthy volunteers.

\section{Statistics}

In the statistical calculations, nonparametric tests (MannWhitney's two-sample, non-matched test, Fisher's exact four-field test, and Spearman's correlation test) were used.

\section{Results}

The characteristics of the patients and the healthy controls are shown in table 1 . Eighteen of the 50 patients with respiratory symptoms had an abnormal methacholine challenge test. There were no statistically significant differences in age, smoking habits, total granulocyte count, or haemoglobin concentration between the three groups. Neither were there any statistically significant differences in the use of antiasthma drugs prior to the challenge test between the hyperreactive and the normoreactive patients, as evaluated with Fisher's test (data not shown). The proportion of atopics/nonatopics was significantly higher in the hyperreactive group (10 out of 18) than in the normoreactive group (3 out of 32 ; $\mathrm{p}<0.001$, Fisher's test).

Figure 1a shows that the hyperreactive patients had a significantly higher PMA-stimulated whole blood CL mean value $\left(18.8 \mathrm{mV} \cdot \mathrm{min}^{-1} ; 95 \%\right.$ confidence limits (C.L.) $\left.16.3-21.3 \mathrm{mV} \cdot \mathrm{min}^{-1}\right)$ than the normoreactive patients $(14.2$ $\mathrm{mV} \cdot \mathrm{min}^{-1} ; 95 \%$ C.L. $\left.13.0-15.5 \mathrm{mV} \cdot \mathrm{min}^{-1} ; \mathrm{p}<0.005\right)$ and the healthy controls $\left(12.8 \mathrm{mV} \cdot \mathrm{min}^{-1} ; 95 \%\right.$ C.L. 11.7-13.9; $\mathrm{p}<0.0005)$. There was no statistically significant difference between the normoreactive patients and the healthy controls, or between the hyperreactive patients with atopy (mean $17.7 \mathrm{mV} \cdot \mathrm{min}^{-1}$; 95\% C.L. $14.8-20.5 \mathrm{mV} \cdot \mathrm{min}^{-1}$ )

Table 1. - Characteristics of the patients and the healthy controls

\begin{tabular}{lccc}
\hline & Normoreactive & Hyperreactive & Healthy \\
\hline $\mathrm{n}$ & 32 & 18 & 15 \\
Smokers $\mathrm{n}$ & 2 & $4^{\dagger}$ & 4 \\
Age yrs & $45 \pm 18$ & $40 \pm 14^{*}$ & $40 \pm 10$ \\
Granulocytes & $4.0 \pm 1.5$ & $4.6 \pm 1.7^{\dagger}$ & $4.0 \pm 1.4$ \\
$\times 10^{6}$ cells $l^{-1}$ & $(3.4-4.5)$ & $(3.8-5.5)$ & $(3.2-4.8)$ \\
$\begin{array}{l}\text { Haemoglobin } \\
\mathrm{g} \cdot l^{-1}\end{array}$ & $138 \pm 10$ & $142 \pm 13^{\dagger}$ & $134 \pm 8$ \\
\hline
\end{tabular}

Values are mean \pm SD with $95 \%$ confidence limits in brackets. $\dagger$ : nonsignificant (Mann-Whitney); *: nonsignificant (Fischer's test) compared to both normoreactive and healthy. a) PMA

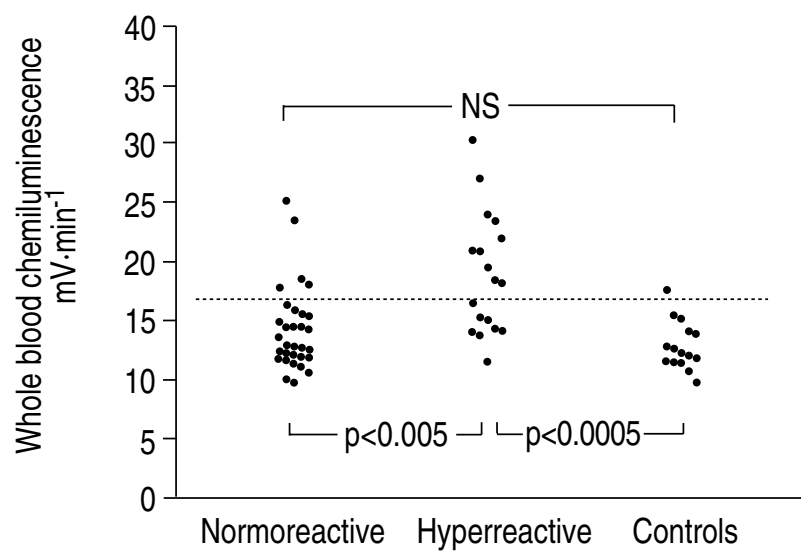

b) Zymosan

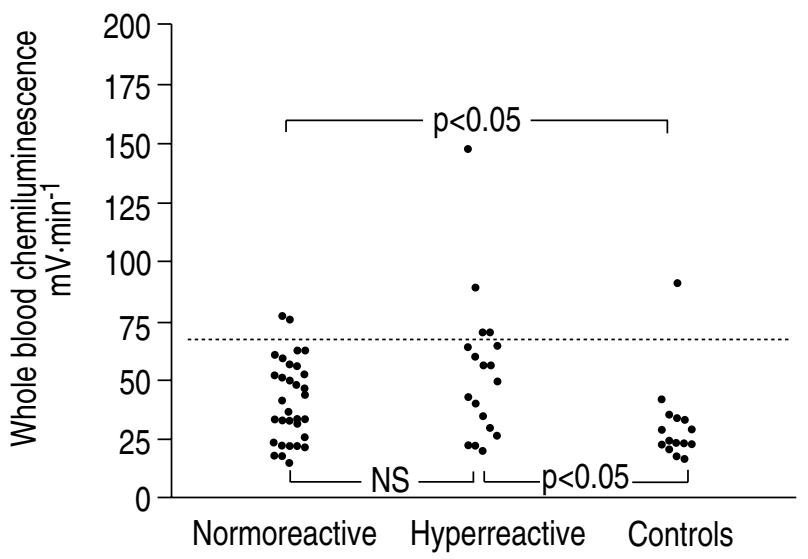

Fig. 1. - Luminol-dependent chemiluminescence from whole blood of normoreactive and hyperreactive patients after stimulation with a) $0.1 \mu \mathrm{g} \cdot \mathrm{ml}^{-1}$ PMA or b) $150 \mu \mathrm{g} \cdot \mathrm{ml}^{-1}$ serum opsonized zymosan compared with the corresponding chemiluminescence values from healthy controls. Each dot represents the mean value of two parallel measurements. Dotted line shows mean +2 SD in the healthy group (=upper normal range). In statistical calculations Mann-Whitney's test was used. NS: nonsignificant; PMA: phorbol 12-myristate 13-acetate.

and those without atopy (mean $20.2 \mathrm{mV} \cdot \mathrm{min}^{-1} ; 95 \%$ C.L. $\left.15.1-25.4 \mathrm{mV} \cdot \mathrm{min}^{-1}\right)$. Using the mean value $\pm 2 \mathrm{SD}$ from the healthy group as the cut-off level, the test had a sensitivity of $56 \%$ and a specificity of $84 \%$ for hyperreactivity versus normoreactivity. There was no correlation between the PMA-stimulated whole blood CL values and the methacholine $\mathrm{PD}_{20} \mathrm{FEV}_{1}$ values in the hyperreactive group (Spearman's correlation coefficient $=0.13$ ).

No statistically significant difference was noted between the zymosan-induced whole blood chemiluminescence values of the hyperreactive and the normoreactive patients (fig. 1b), but both groups had significantly higher values than the healthy controls $(\mathrm{p}<0.05)$.

There were no significant differences in monocyte ROM production between the hypereactive and normoreactive group, either when PMA or when opsonized zymosan was used as stimulant (data not shown). No close correlation between the total granulocyte count and PMAinduced whole blood chemiluminescence was observed (Spearman's correlation coefficient $=0.34$ ). 
a) ECP

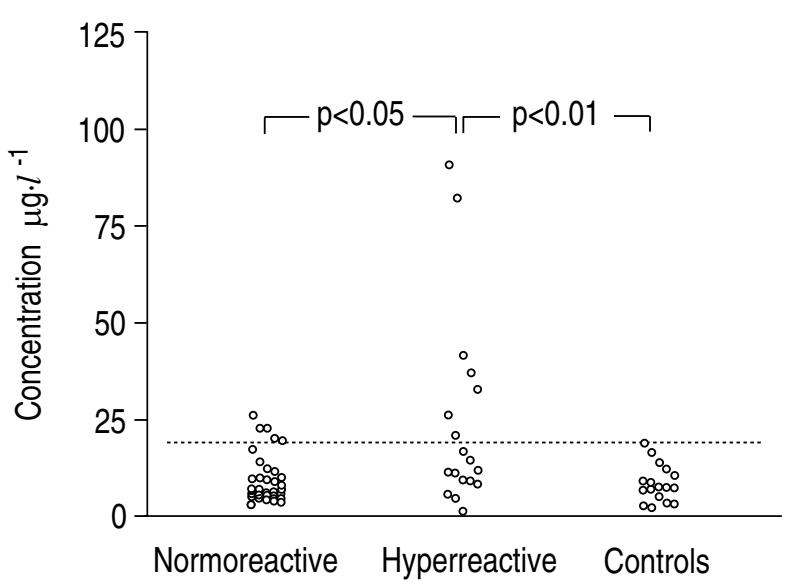

b) MPO

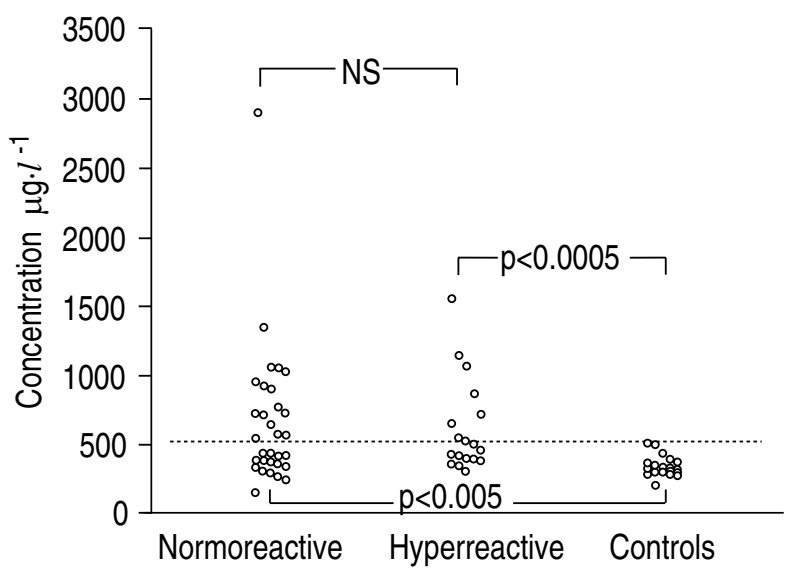

Fig. 2. - a) Serum ECP and b) MPO values from normoreactive and hyperreactive patients compared to 17 healthy controls. Data from one normoreactive patient is missing. Dotted line shows mean+2 SD in the healthy group. In statistical calculations Mann-Whitney's test was used. ECP: eosinophilic cationic protein; MPO: myeloperoxidase.

The hyperreactive patients had higher serum ECP values (mean $24.4 \mu \mathrm{g} \cdot \mathrm{l}^{-1}$; 95\% C.L. 11.7-36.8 $\mu \mathrm{g} \cdot \mathrm{l}^{-1}$ ) than the normoreactive patients (mean $10.2 \mu \mathrm{g} \cdot l^{-1} ; 95 \%$ C.L. $7.9-12.5 \mu \mathrm{g} \cdot l^{-1} ; \quad \mathrm{p}<0.05$ ) and 17 healthy controls (mean $8.5 \mu \mathrm{g} \cdot l^{-1} ; \quad 95 \%$ C.L. $6.0-10.9 \mu \mathrm{g} \cdot l^{-1}$ ) (fig. 2a). Using the mean value+2 SD from the controls as the cut-off level, the test had a sensitivity of $39 \%$ and a specificity of $84 \%$ for hyperreactivity versus normoreactivity. There was no correlation between the PMA-induced whole blood chemiluminescence values and the serum ECP values (Spearman's correlation coefficient $=-0.07$ ) or between PMA-induced whole blood chemiluminescence and total eosinophil count $(n=28$; Spearman's correlation coefficient $=0.35$ ). No statistically significant difference in serum MPO values between the hypereactive (mean 621 $\mu \mathrm{g} \cdot \mathrm{l}^{-1} ; \quad 95 \%$ C.L. $\left.454-789 \mu \mathrm{g} \cdot l^{-1}\right)$ and normoreactive patients (mean $667 \mu \mathrm{g} \cdot l^{-1} ;$ 95\% C.L. 482-856 $\mu \mathrm{g} \cdot l^{-1}$; $\mathrm{p}=0.84$ ) was noted, but both groups had significantly higher values than the healthy controls (mean $355 \mu \mathrm{g} \cdot l^{-1}$; 95\% C.L. 315-395 $\mu \mathrm{g} \cdot l^{-1} ; \mathrm{p}<0.005$ ) (fig 2b). There was no correlation between the PMA-induced whole blood chemiluminescence values and the serum MPO values (Spearman's correlation coefficient $=0.12$ ).

\section{Discussion}

The results of this study show higher PMA-induced chemiluminescence values from whole blood of patients with bronchial hyperreactivity than of normoreactive patients and healthy controls. Higher serum ECP values were also noted in the hyperreactive group than in the normoreactive group, whilst serum MPO was equally elevated in both patient groups.

As mentioned above, increased capacity to ROM production by isolated peripheral blood neutrophils of patients with asthma has been reported previously by several groups. A correlation between neutrophil ROM production and bronchial hyperreactivity has been shown both in bronchial asthma [17, 19], and in chronic obstructive pulmonary disease [32]. The magnitude of the neutrophil ROM responses has been reported to correlate with the severity of asthma symptoms [19]. The chemiluminescence signal obtained from whole blood is predominantly a function of neutrophil number and function [33], whilst the contribution of monocytes, lymphocytes and thrombocytes has been considered negligible [22, 34-37]. We observed no close correlation between total granulocyte count and the PMA-induced whole blood chemiluminescence values, which suggests that the chemiluminescence responses were not merely a function of neutrophil number, but also of neutrophil metabolic activity.

We could not observe any significant difference in chemiluminescence responses from the mononuclear cell suspensions of the hyperreactive and normoreactive patients, which suggests that the higher PMA-induced whole blood chemiluminescence values were not due to an activation of monocytes in the hyperreactive group. However, an increased ROM production by monocytes both in asthma [20,38], and in atopy [39] has been reported. Eosinophils from peripheral blood of asthmatic patients also generate increased amounts of ROMs [18], and these cells might also have contributed to our chemiluminescence results. Several studies have reported elevated serum ECP levels in asthmatic patients, suggesting an activation of eosinophils in asthma (reviewed recently by VENGE [25]). In agreement with these studies, we also observed increased ECP values in the hyperreactive group, but there was no correlation between PMAinduced whole blood chemiluminescence and serum ECP levels or eosinophil count, respectively. Also, the chemiluminescence values were not higher in the atopic hyperreactive patients than in the nonatopic subjects, which speaks against a central role for eosinophil-derived ROMs in PMA-induced whole blood chemiluminescence.

Thus, we suggest that the increased PMA-induced whole blood chemiluminescence responses were due mainly to ROMs produced by metabolically activated neutrophils. The elevated serum MPO values in the hyperreactive group also suggest an activation of neutrophil ROM production, but the MPO levels in the normoreactive group were equally increased. Possibly 
a common reason for the prolonged cough and/or dyspnoea in the normoreactive group was a subacute bacterial infection, which may explain the increase in serum MPO in this group. Earlier reports concerning serum MPO as an inflammatory marker in asthma have been negative $[40,41]$.

Only whole blood chemiluminescence induced by PMA was increased in the hyperreactive group. In a recently published study by NIELSON et al. [42], whole blood chemiluminescence responses to the bacterial peptide formyl-methionyl-leucyl-phenylalanine (FMLP) were higher in a group of hyperreactive patients, whilst there were no differences in the responses to the calcium ionophore A23187. Thus, the activation of the phagocytes responsible for the increased whole blood chemiluminescence seems to be selective for certain NADPH oxidase stimulants. The biochemical mechanisms for this finding remain to be explained.

Whole blood chemiluminescence is affected by haemoglobin concentration and serum factors [22, 35, 43, 44]. In our study, the variation in haemoglobin concentration between the patient groups was small; thus, we did not find it necessary to correct the chemiluminescence values for haemoglobin. A correction according to the study by Ristola and REPO [22] did not change the results significantly. Serum in physiological concentrations has an inhibitory effect on luminol-dependent chemiluminescence [44], which may be due, in part, to the presence of antioxidants in serum. Several investigators have shown that asthmatics have lower antioxidant levels in serum $[45,46]$. Thus, the higher whole blood chemiluminescence responses in the hyperreactive group might also have been due, in part, to decreased antioxidant levels in serum. However, this effect would probably also have been observed when opsonized zymosan was used as stimulant, which was not the fact.

In conclusion, our results suggest that PMA-induced whole blood chemiluminescence might be useful in detecting a systemic effect of pulmonary inflammatory processes resulting in bronchial hyperreactivity. In our study, the test had a higher sensitivity for bronchial hyperreactivity than serum ECP determination, which has recently been suggested as an inflammatory marker in asthma [25], and as good a specificity. Work is in progress to evaluate whole blood chemiluminescence as an inflammatory marker in the longitudinal follow-up of individual patients with verified asthma during treatment.

Acknowledgements: The authors thank H. Riska, M. Klockars and O. Selroos for their advice and support.

\section{References}

1. Montefort S, Herbert CA, Robinson C, Holgate ST. The bronchial epithelium as a target for inflammatory attack in asthma. Clin Exp Allergy 1992; 22: 511520.

2. Bousquet J, Chanez P, Lacoste JY, et al. Asthma: a disease remodeling the airways. Allergy 1992; 47: 311.
3. Laitinen LA, Laitinen A. Pathology and cytology of asthma. In: Clark TJH, Godfrey S, Lee TH, eds. Asthma. 3rd edn. London, Chapman \& Hall Medical, 1992: pp. 232-253.

4. Laitinen LA, Laitinen A, Haahtela T. Airway mucosal inflammation even in patients with newly diagnosed asthma. Am Rev Respir Dis 1993; 147: 697-704.

5. Bellavite P. The superoxide-forming enzymatic system of phagocytes. Free Rad Biol Med 1988; 4: 225-261.

6. Halliwell B. Reactive oxygen species in living systems: source, biochemistry and role in human disease. Am J Med 1991; 91 (Suppl. 3C): 14S-22S.

7. Babior BM. Oxygen-dependent microbial killing by phagocytes. N Engl J Med 1978; 298: 659-668, 721-725.

8. Bast A, Haenen GRMM, Doelman CJA. Oxidants and antioxidants: state of the art. Am J Med 1991; 92 (Suppl. 19 3C): 2S-13S.

9. Cluzel M, Damon M, Chanez P, et al. Enhanced alveolar cell luminol-dependent chemiluminescence in asthma. J Allergy Clin Immunol 1987; 80: 195-201.

10. Kelly C, Ward C, Stenton CS, Bird G, Hendrick DJ, Walters EH. Number and activity of inflammatory cells in bronchoalveolar lavage fluid in asthma and their relation to airway responsiveness. Thorax 1988; 43: 684692.

11. Damon M, Cluzel M, Chanez P, Godard P. Phagocytosis induction of chemiluminescence and chemoattractant increased superoxide anion release from activated human alveolar macrophages in asthma. J Biol Chem 1989; 4: 279-286.

12. Ward C, Kelly CA, Stenton SC, Duddridge M, Hendrick DJ, Walters EH. The relative contribution of bronchoalveolar macrophages and neutrophils to lucigeninand luminol-amplified chemiluminescence. Eur Respir $J$ 1990; 3: 1008-1014.

13. Calhoun WJ, Reed HE, Moest DR, Stevens CA. Enhanced superoxide production by alveolar macrophages and airspace cells, airway inflammation, and alveolar macrophage density changes after segmental antigen bronchoprovocation in allergic subjects. Am Rev Respir Dis 1992; 145: 317-325.

14. Jarjour NN, Busse WW, Calhoun WJ. Enhanced production of oxygen radicals in nocturnal asthma. Am Rev Respir Dis 1992; 146: 905-911.

15. Neijens HJ, Raatgeep RE, Degenhart HJ, Duiverman EJ, Kerrebijn KF. Altered leukocyte response in relation to the basic abnormality in children with asthma and bronchial hyperresponsiveness. Am Rev Respir Dis 1984; 130: 744-747.

16. Sustiel AM, Joseph B, Rocklin RE, Borish L. Asthmatic patients have neutrophils that exhibit diminished responsiveness to adenosine. Am Rev Respir Dis 1989; 140: $1556-1561$.

17. Meltzer S, Goldberg B, Lad P, Easton J. Superoxide generation and its modulation by adenosine in the neutrophils of subjects with asthma. J Allergy Clin Immunol 1989; 83: 960-966.

18. Chanez P, Dent G, Yukawa T, Barnes PJ, Chung KF. Generation of oxygen free radicals from blood eosinophils from asthma patients after stimulation with PAF or phorbol ester. Eur Respir J 1990; 3: 987-988.

19. Kato M, Nakano H, Morikawa A, Kimura H, Shigeta M, Kuroume T. Ability of polymorphonuclear leukocytes to generate active oxygen species in children with bronchial asthma. Use of chemiluminescence probes with a Cypridina luciferin analog and luminol. Int Arch Allergy Appl Immunol 1991; 95: 17-22. 
20. Vachier I, Damon M, Le Douchen C, et al. Increased oxygen species generation in blood monocytes of asthmatic patients. Am Rev Respir Dis 1992; 146: 11611166.

21. DeChatelet LR, Shirley PS. Evaluation of chronic granulomatous disease by a chemiluminescence assay of microliter quantities of whole blood. Clin Chem 1981; 27: 1739-1741.

22. Ristola M, Repo H. Luminol-enhanced chemiluminescence of whole blood. APMIS 1989; 97: 503-512.

23. American Thoracic Society. Standards for the diagnosis and care of patients with chronic obstructive pulmonary disease (COPD) and asthma. Am Rev Respir Dis 1987; 136: 225-244.

24. O'Byrne PM. Airway responsiveness to pharmacological agents. In: Clark TJH, Godfrey S, Lee TH, eds. Asthma. 3rd edn. London: Chapman \& Hall Medical, 1992: pp. 108-132.

25. Venge P. Serum measurements of eosinophilic cationic protein (ECP) in bronchial asthma. Clin Exp Allergy 1993; 23 (Suppl. 2): 3-7.

26. Midander J. Clinical documentation of inflammation markers in asthma. Clin Exp Allergy 1993; 23 (Suppl. 2): 13-14.

27. Hedenborg M. Titanium dioxide induced chemiluminescence of human polymorphonuclear leukocytes. Int Arch Occup Environ Health 1988; 61: 1-6.

28. Sovijärvi ARA, Malmberg LP, Reinikainen K, Rytilä P, Poppius H. A rapid dosimetric method with controlled tidal breathing for histamine challenge. Chest 1993; 104: 164-170.

29. Nieminen MM, Lahdensuo A, Kellomäki L, Karvonen J, Muittari A. Methacholine bronchial challenge using a dosimeter with controlled tidal breathing. Thorax 1988; 43: 896-900.

30. Peterson CGB, Enander I, Nystrand J, Anderson AS, Nilsson L, Venge P. Radio-immunoassay of human eosinophilic cationic protein (ECP) by an improved method. Establishment of normal levels in serum and turn-over in vivo. Clin Exp Allergy 1991; 21: 561-567.

31. Olofsson P, Olsson I, Venge P, Elgefors B. Firm myeloperoxidase and lactoferrin in neutropenia. Scand J Hematol 1977; 18: 77-80.

32. Postma DS, Renkema TE, Noordhoek JA, Faber H, Sluiter HJ, Kauffman H. Association between nonspecific bronchial hyperreactivity and superoxide production by polymorphonuclear leukocytes in chronic airflow obstruction. Am Rev Respir Dis 1988; 137: 57-61.

33. DeSole P. Polymorphonuclear chemiluminescence: some clinical applications. J Biolumin Chemilumin 1989; 4: 251-262.
34. Sagone AL, King GW, Metz EN. A comparison of the metabolic response to phagocytosis in human granulocytes and monocytes. J Clin Invest 1976; 57: 1352-1358.

35. DeSole P, Lippa S, Littarru GP. Whole blood chemiluminescence: a new technical approach to assess oxygendependent microbial activity of granulocytes. J Clin Lab Autom 1983; 3: 391-400.

36. Müller A, Schuff-Werner P, Wurl M, Nagel GA. Reliability of the detection of human monocyte chemiluminescence in mononuclear suspensions. In: Kricka LJ, Stanley PE, Thorpe GHG, Whitehead TP, eds. Analytical Applications of Bioluminescence and Chemiluminescence. Orlando, Academic Press. 1984; pp. 343-346.

37. Fisher H, Kato T, Wokalek H, Ernst M, Eggert H, Rietschel ET. Measurements of granulocyte and platelet chemiluminescence in small samples of whole blood. In: DeLuca MA, McElroy WD, eds. Bioluminescence and Chemiluminescence. Basic Chemistry and Analytical Applications. New York, Academic Press, 1981; pp. 617-622.

38. Durham SR, Carroll M, Walsh GM, Kay AB. Leukocyte activation in allergen-induced late-phase asthmatic reactions. N Engl J Med 1984; 311: 1398-1402.

39. Polla BS, Ezekowitz RA, Leung DYM. Monocytes from patients with atopic dermatitis are primed for superoxide production. J Allergy Clin Immunol 1992; 89: 545-551.

40. Kallenbach J, Baynes R, Fine B, Dajee D, Bezwoda W. Persistent neutrophil activation in mild asthma. J Allergy Clin Immunol 1992; 90: 272-274.

41. Griffin E, Håkansson L, Formgren H, Jörgensen K, Peterson C, Venge P. Blood eosinophil number and activity in relation to lung function in patients with asthma and with eosinophilia. J Allergy Clin Immunol 1991; 87: 548-557.

42. Nielson CP, Crowley JJ, Vestal RE, Connolly MJ. Impaired beta-adrenoceptor function, increased leukocyte respiratory burst, and bronchial hyperresponsiveness. $J$ Allergy Clin Immunol 1992; 90: 825-832.

43. Tono-Oka T, Ueno N, Matsumoto T, Ohkawa M, Matsumoto S. Chemiluminescence of whole blood. 1. A simple and rapid method for the estimation of phagocytic function of granulocytes and opsonic activity in whole blood. Clin Immunol Immunopathol 1983; 26: 66-75.

44. Faden H, Maciejewski N. Whole blood luminol-dependent chemiluminescence. J Reticuloendothel Soc 1981; 30: 219-226.

45. Burney PGJ. Epidemiology. In: Clark TJH, Godfrey S, Lee TH, eds. Asthma. London, Chapman \& Hall Medical. 1992: pp. 254-307.

46. Doelman CJA, Bast A. Oxygen radicals in lung pathology. Free Rad Biol Med 1990; 9: 381-400. 